\title{
Christian attitudes in scholarship: The role of worldviews
}

\begin{abstract}
Author:
Renato Coletto ${ }^{1}$

Affiliation:

${ }^{1}$ School of Philosophy,

Potchefstroom Campus,

North-West University,

South Africa

Correspondence to:

Renato Coletto

Email:

renato.coletto@nwu.ac.za

Postal address:

Private Bag X6001,

Potchefstroom 2520,

South Africa

Dates:

Received: 06 June 2011

Accepted: 30 Jan. 2012

Published: 14 Nov. 2012

How to cite this article: Coletto, R., 2012, 'Christian attitudes in scholarship: The role of worldviews', Koers - Bulletin for Christian Scholarship 77(1), Art. \#33, 10 pages. http://dx.doi.org/ 10.4102/koers.v77i1.33

Note:

This article was developed from a paper delivered at the Koers-75 Conference on 'Worldview and Education', held in Potchefstroom, South Africa, from 30 May to 02 June 2011.
\end{abstract}

Hierdie artikel is ' $n$ verdere ontwikkeling van ' $n$ voordrag gelewer by die Koers-75 Konferensie oor 'Worldview and Education' in Potchefstroom, Suid-Afrika, vanaf 30 Mei tot 02 Junie 2011.

(C) 2012. The Authors. Licensee: AOSIS OpenJournals. This work is licensed under the Creative Commons Attribution License.
This article starts from the realisation that a few different approaches to science and scholarship are implemented within different Christian traditions. In an attempt at identifying the reasons behind such differences, it is argued that the approach to science and scholarship adopted in each Christian tradition corresponds to a considerable extent to the worldview accepted in that tradition. In this article, several versions of the main Christian worldviews are identified and related to the work of authors (e.g. Murphy, the Theonomic movement, Barbour, Van Huyssteen, Wolterstorff) who were not discussed in previous works on this topic. The possibility of 'mixing' the worldviews (thus adopting an eclectic approach) is also discussed. The proposed taxonomy may be used to understand at a deeper level both individual authors and trends, and also to sketch a 'map' of the different movements, contributors and available options. It is argued that the different worldviews are not equally valuable and that the reformational worldview should be regarded as more integrally and originally biblical. The article ends with a call to consistency for the sake of sound Christian scholarship.

Christelike houdings in wetenskap: Die rol van wêreldbeskouings. Hierdie artikel begin met die besef dat ' $n$ aantal verskillende benaderings tot tot wetenskap binne verskillende Christelike tradisies geïmplementeer word. In 'n poging om die redes vir sodanige verskille te identifiseer, word aangevoer dat die benadering tot wetenskap wat in elke Christelike tradisie aangeneem word, tot 'n groot mate met die aanvaarde wêreldbeskouing van daardie tradisie ooreenstem. In hierdie artikel word ' $\mathrm{n}$ aantal weergawes van die belangrikste Christelike wêreldbeskouings geïdentifiseer en in verband gebring met die werk van outeurs (bv. Murphy, die Teonomiese beweging, Barbour, Van Huyssteen, Wolterstorff) wat nie in vorige werke oor hierdie onderwerp bespreek is nie. Die moontlikheid om die verskillende wêreldbeskouings te 'meng' (en dus 'n eklektiese benadering te volg) word ook bespreek. Die voorgestelde taksonomie kan moontlik gebruik word om sowel individuele outeurs as tendense in meer diepte te verstaan, asook om ook ' $n$ 'kaart' van die verskillende bewegings, bydraers en beskikbare opsies, te skets. Daar word aangevoer dat die verskillende wêreldbeskouings nie gelykwaardig is nie en dat die reformatoriese wêreldbeskouing as meer integraal en oorspronklik Bybels geag moet word. Die artikel sluit af met ' $n$ oproep tot konsistensie ter wille van behoorlike Christelike wetenskap.

\section{Orientation}

Different Christian circles traditionally approach scholarship ${ }^{1}$ (and specific issues within the various disciplines) in different ways. This article will focus especially on how different Christian traditions (1) understand and elaborate Christian scholarship, (2) relate to non-Christian scholarship and (3) approach the creation-evolution debate (a sub-topic of the previous theme).

The differences in approach do not seem to be dictated by different doctrinal and ecclesiastical positions. In fact, members of the same confessional traditions can differ substantially in their attitude towards scholarship. Where do the differences come from? In the following pages, I propose the thesis that such differences have much to do with the different Christian worldviews ${ }^{2}$.

A basic purpose of this article is to show that by studying the Christian attitudes in scholarship along worldview-lines, we can obtain a fair understanding of the trends and positions in this field. Another purpose is to show that worldviews and attitudes are not just the same, and one needs to

1.The terms scholarship and science are used as synonyms and include both natural sciences and humanities, in other words all academic disciplines. The phrase scholarship and science is sometimes used with the same meaning.

2.The term worldview is hereby used in the sense of 'set of fundamental convictions/attitudes'. The term paradigm is used as a synonym of worldview. Some might argue that what I discuss in this article is to be understood as the influence of a religious ground motive (according to Dooyeweerd, the ultimate religious grounding of worldviews). I have no objection to this understanding, and it does not make a crucial difference concerning the main thesis of this work, namely that different attitudes to scholarship derive from a set of fundamental patterns. 
make appropriate choices. This article also aims, therefore, at empowering the reader for making better choices by indicating the basic strategies of the main Christian worldviews, their basic starting points, their problems and their resources.

Although the present topic has already received considerable attention within Christian and (more specifically) reformational circles (cf. Niebuhr 1956; Olthuis 1970; Wolters 1990; Van der Walt 2001) this article is not a mere survey of past contributions. In fact, it introduces and explores the particular 'versions' of most of the worldviews (see scheme below). Furthermore, such versions are discussed in relation to authors who were not mentioned in previous works on this topic. Finally, the possibility of 'mixing' the worldviews (i.e. the possibility of an eclectic approach) is also discussed.

\section{The main Christian worldviews \\ Basic characteristics}

It was Bavinck (1888) who sketched the characteristics of various Christian worldviews for the first time, followed by Niebuhr's (1956) famous work Christ and culture. For the reformational school, authors like Wolters (1990) and Van der Walt (2001) have continued the tradition and reworked the classifications. I propose that the fundamental Christian worldviews can be 'captured' in the categories indicated in Table 1.

These worldviews are here presented in order of historical appearance (with the exception of the reformational model, discussed last). Olthuis (1970) prefers to discuss them in a difference sequence, namely (1) Liberal, (2) Catholic, (3) Lutheran and (4) Anabaptist. In this sequence, he distinguishes a left (Liberal) and a right (Anabaptist) side and the more moderate centre-left (Catholic) and centre-right (Lutheran) positions. His layout is more systematic and mine is more historical.

As one may observe, in the first four worldviews a basic distinction is drawn between a sphere of nature and a sphere of grace. Concerning scholarship, in most cases theology is regarded as belonging to the sphere of 'grace', whilst the other disciplines belong to 'nature'.

Common to most of these approaches is a wish to account for the relationship between theology and scholarship (after the initial distinction along nature-grace lines). Another common trait is the belief that today's theology is not credible to the contemporary man, the 'bridge' between theology and science is damaged ${ }^{3}$ and a better interaction with the 'scientific age' is the key to recover the poor reputation of theology. The nature-grace approaches differ, however, on the relationship that they wish to establish between the two 'realms'.

The reformational model has a different starting point. Although it could be described (in terms of the nature-grace terminology) as 'grace transforming nature' (cf. Wolters 1990), I would argue that the nature-grace formula does not adequately define this approach. In fact, the latter does not start from a two-realm distinction. Following this model, scholarship and religious ground motives are always and already integrated, and the reconciliation between secular science and theology (often incorrectly identified with religion or Christianity) is not perceived as a major problem.

Before proceeding, it is appropriate to specify that, although worldviews are traditionally related to a certain ecclesiastical or confessional tradition (Catholic, Lutheran, etc.), the adoption of a worldview does not always imply the adoption of the related ecclesiastical or doctrinal tradition as well.

A brief preliminary survey of the basic consequences of the adoption of each worldview might be helpful.

\section{Basic inclinations and consequences}

In the Catholic model, the science of grace (theology) has a certain priority over the sciences related to nature or creation. The Lutheran approach adopts a parallelism which tries to harmonise the two realms. In the Anabaptist model, a basic conflict between nature and grace is presupposed. Secular science (and sometimes science tout court) cannot bring about anything positive and is therefore opposed. The Liberal model tends to identify the Christian position in scholarship with some or other secular position. Christian theology is often 'shaped' by for example, evolutionism, socialism and so forth.

Finally, the Reformational worldview tries to escape the nature-grace duality and affirms that everything in reality and culture is created, fallen, but also open to restoration. The articulation of a Christian philosophy and scholarship in dialogue with other trends, is the relevant trait of this approach.

In the next sections, we are going to articulate the hypothesis that there is a fair correlation between the main worldviews 3.The idea is vividly illustrated on the front cover of the journal Theology and Science, which used to present a broken bridge. (It is interesting to see that since 2008, that is volume 6 , the bridge has been repaired. I have no idea about the meaning of the change.)

TABLE 1: Classification of Christian worldviews.

\begin{tabular}{|c|c|c|c|c|c|}
\hline Worldview type & Catholic & Lutheran & Anabaptist & Liberal & Reformational \\
\hline Basic pattern & Grace above nature & Grace alongside nature & Grace against nature & Grace within nature & Creation, fall, redemption \\
\hline Key-idea & Integration & Parallelism & Opposition & Identification & Reformation \\
\hline Versions & $\begin{array}{l}\text { 1. Control } \\
\text { 2. Mysticism }\end{array}$ & $\begin{array}{l}\text { 1. Isolation } \\
\text { 2. Concordance }\end{array}$ & $\begin{array}{l}\text { 1. Separation } \\
\text { 2. Substitution }\end{array}$ & $\begin{array}{l}\text { 1. Adoption } \\
\text { 2. Elaboration }\end{array}$ & Inner-reformation \\
\hline
\end{tabular}


and the way science and scholarship are conceived and pursued within Christian circles. We will also associate some worldviews with specific movements and authors, although we will hopefully resist the temptation of simply 'fitting' authors in narrow boxes created or required by our own method.

\section{A Catholic approach to science and scholarship}

\section{Synthesis and integration}

The main feature of this approach is that the line between nature and grace is drawn horizontally, so that the two realms are situated one above the other (grace above nature). The aim is to give a certain priority to the sphere of grace. In the Catholic tradition, at least one science (i.e. theology) falls within the sphere of grace and is related especially to faith and to the written and incarnated revelation. The other sciences or disciplines are related to the creational revelation and to reason, and in this sense, they are not supposed to affect the faith-sphere in dramatic ways.

Of course, the fact that an academic may take faith and theology into account may create certain differences in their approach to scholarship. Theology may not question the results of the sciences but can influence or even direct them according to the motto 'gratia natura non tollit, sed perficit' [grace does not eliminate nature but perfects it]. Historically speaking, perficit has been mainly understood as (1) to complete, to bring to perfection and (2) to elevate. However, completion (or integration) has normally overshadowed elevation (Veenhof 1994:9). This is illustrated in our scheme by calling 'integration' the basic idea of this model.

On the one hand, theology will therefore try to influence scholarship. Conversely, although the extra-theological sciences are not supposed to prescribe anything in the theological domain, they remain ancillae [handmaids] and they can, as a consequence, offer an external support to theology. The Catholic tradition, therefore, does not endorse a simplistic model but rather promotes a 'symphonic' cooperation of the different disciplines.

On the less positive side, one may notice that control does not imply any transformation of 'nature' but rather integration: Grace 'floats' on top of nature like oil floating on water (Bavinck 1888:21). In addition, although grace remains in control of nature and performs the necessary integration, control is achieved on the basis of a previous synthesis or accommodation. ${ }^{4}$ The most famous example concerns the scholastic synthesis between Christian doctrine and Aristotelian philosophy.

As the secular theories and trends in a certain field are usually many, which ones should be selected to be integrated in such a synthesis? The Catholic approach tends to opt

4.Dooyeweerd (1959:35) notices precisely this fact in relation to the approach of Thomas Aquinas and scholastic philosophy in general. No transcendental critique is possible in the sphere of 'nature' [praeambula gratiae] because these are matters of reason, not of faith. The next step is accommodation. for moderation, balance and catholicity (i.e. universality). The Christian position, when possible, should reflect and incorporate in itself the entire spectrum of the available options (the specific positions will then be regarded as fragments or aspects of the universal or Catholic fullness). In politics, for example, the Catholic parties tend to occupy the 'centre', a position from which the 'opposite extremes' are incorporated and moderated. ${ }^{5}$

In the creation-evolution debate the theory of evolution is accepted but integrated by means of a non-deistic interpretation and (in the case of human evolution) by the doctrine of the addition of the soul to the bodies of the first human beings. This may be regarded as a form of theistic evolutionism. However, it is not the only option available to the Catholic scholar. ${ }^{6}$

Before moving to some examples, we can just point out that, in Catholic circles, the strategy of 'control' has not been the only option. It is also possible to find a shelter in the superior realm of grace. Historically, this attitude is illustrated by phenomena like monasticism and mysticism which are endorsed, however, much less frequently than the controlapproach.

\section{Examples of control-strategies}

A good example of a 'grace above nature' approach, I believe, is to be found in the work of Murphy. Like many Christian authors, she would like to 'reconcile' theology and science (after dividing them along the nature-grace duality).

Murphy's plan, however, includes also the recovery of a better role for theology, which is for the moment still relegated to a position of scarce reliability. How can one achieve this goal? Murphy's (1990:174-191) strategy is to show that theology meets the standards of scientific rationality.

How are these standards determined? Are they theological or scientific? Are they secular or Christian? Murphy's answer is that the standards must be objective, 'public' in the sense that they should reflect recent criteria for scientific rationality. Her choice falls on Lakatos's philosophy (Murphy 1990:51-87), a trend in the Popperian tradition but more recent than Popper's and well balanced between (even integrative of?) positivism and relativism.

Unfortunately, no transcendental critique of those standards is in view, and she has no hesitation in adopting a secular approach. A better demarcation criterion (Coletto 2011a:76-77, 2011b) would be available in Christian philosophy, but for Murphy, secular is synonymous to 'public'. Nevertheless, why would she

5.In some cases, however, it may happen that the Catholic choice has to privilege a specific trend. In philosophy, for example, after considering the age-old dilemmas of realism versus nominalism, some version of realism was usually preferred.

6.Strauss (2009:638ff.) regards theistic evolutionism in general as a form of neoscholasticism. Klapwijk (2008:12-28) regards also 'intelligent design' as a movement inspired by a Catholic approach. One of the reasons is that rationality constitutes a kind of 'natural' support for faith (Klapwijk 2008:22-23). 
prefer Lakatos's demarcation criterion to the one provided by, for example, Kuhn or Popper? Of course, she argues that Lakatos' philosophy is preferable, but it is not difficult to see that she chooses the author who allows her to conclude that theology can be scientific.

In fact, theology is declared scientific (Murphy 1990:88-173), or at least, all the theological trends which (in line with Lakatos's philosophy) can be regarded as progressive 'research programmes' can be declared scientific. Once this has been achieved, Murphy's next question, in line with the 'above nature' approach, is: Can theology also influence or direct other sciences? The answer is affirmative (Murphy 1985; 1990:197-198), and therefore, the Catholic approach finds in this scholar a perfect supporter.

I would like to briefly mention a second example. I (Coletto 2009:31) have recently explored the hypothesis that (at least some authors in) the Vantilian school, although officially defending and promoting a reformed position, may in fact be (at least in part) representative of a Catholic approach to scholarship.

In fact, the way theology is treated, defined and used shows clear links with the 'above nature' scheme. ${ }^{7}$ In practice, theology assumes amongst the sciences the same position as the clergy in the Catholic Church. As a detailed discussion of the similarities between the two areas (ecclesiastical and encyclopaedic) would require too much space, I refer the reader to my (Coletto 2009) article.

\section{A Lutheran approach} The main characteristics

In the Lutheran tradition the line between nature and grace is drawn vertically, thus creating a parallelism. Technically speaking, the two realms are 'parallel' even in the Catholic approach, but in this case, no primacy is implied, but rather a well-balanced and 'egalitarian' relationship. In this case too, at least two different versions of the basic paradigm are available.

In the first version, parallelism may lead to isolation of the two realms, to the point that they have little in common. In classical geometry, two lines are parallel when they never touch each other, even if extended ad infinitum. One may think for example of Cardinal Baronio who, dealing with the Copernican controversy, coined the famous sentence: 'The Bible is about how to go to heaven, not about how the heavens go'. In this case, the two realms are kept in peaceful co-existence but also in stern isolation (the Bible has nothing to say, basically, on scholarly issues). Now, most Christians

7.One should notice, at this point, that both in the Vantilian school and in Murphy's work, one of the most problematic issues is their understanding and definition of theology. For Murphy (1990:22) it 'relates all things to the God of the Bible' (what about Islamic theology?) For Frame (1987:76) it 'applies God's Word to all spheres of life' (no need for other Christian perspectives?). In the above-quoted article (Coletto 2009:20ff.), I have complained that, due to improper definitions of theology, often the differences between worldview, theology and faith are lost. am pleased to realise that, during the same period, Pierson (2009:34) of Trinity University (Chicago) has pointed out similar problems (e.g. in Murphy's work). perceive this position as un-convincing. Its moment of truth lies in the idea that the Bible is not a 'manual' for astronomy or chemistry, but does it mean that it has nothing at all to say on those issues?

On the other hand, parallelism might be interpreted in a more 'concordist' sense, to borrow Blocher's (1984:5) term. In this case, there will be a strong inclination at harmonising what we read in the Bible with the (most recent) findings (e.g. of biology, politics or economics).

We may also observe that, systematically speaking, concordance can deviate in two directions: A certain priority may be attributed to theology or to non-theological sciences. The more priority is given to theology, the more one moves towards a Catholic position (i.e. theology above scholarship). On the other hand, the more one follows the opposite direction, the more one is open to a Liberal approach (we may call it 'science above theology'). ${ }^{8}$ In order to remain within the Lutheran worldview, therefore, concordance must be characterised by moderation and balance.

These last observations constitute a first acknowledgment of the fact that the nature-grace worldviews are not closed compartments but rather variations of the same basic pattern originating in Catholic Christianity. Other possible interconnections (or oppositions) between the models will be pointed out below. For the moment, let us focus on some examples of isolation and concordance.

\section{Examples of isolation-scholarship}

There has been much debate on the question whether Barth's theology should be considered reformed or (neo-) Liberal. In fact, he tried to recover aspects of the classical Calvinist position whilst to a certain extent fighting theological Liberalism. From a worldview perspective, however, perhaps Barth's contribution could be classified as a Lutheran project. As a matter of fact, he does not accept any point of contact between the poles of nature and grace (Dooyeweerd 1984:66).

Barth even eliminates all links between the sphere of rationality (nature) and the sphere of theology (grace). Due to this fact, Olthuis (1970:121) places Barth within the Anabaptist model. Whilst this may be slightly excessive, it is not unreasonable, especially considering that Barth reaches the well-known conclusion that developing a Christian philosophy is not possible and that theology should not look for philosophical support. ${ }^{9}$ However, the dialectical nature of his theology fits quite well, in my opinion, in the isolationtype of worldview.

One issue to explore further is the possible link between the Lutheran and Kantian attitudes of isolation. Although

8.The usual designation for the Liberal worldview is 'grace within nature', but in this approach secular scholarship has such an authority on Christian theorising that 'nature above grace' (hence 'science above theology') may be an alternative definition.

9.Of course, the fact that formally Barth does not accept the influence of philosophy .Of course, the fact that formally Barth does not accept the influence of philosophy
on theology does not mean that he is 'free' from philosophy. In fact, his theological work is deeply affected by philosophers like Kierkegaard (by coincidence: a Lutheran!) and other German existentialists. 
stemming from different ground motives (one Christian and one humanist), they present considerable similarities. This, however, is about the past.

A recent (and South African) example of isolationscholarship may be provided by the work of Van Niekerk (2005:167-193). Attempts at creating bridges between 'faith and science' are not totally absent in Van Niekerk's work (cf. 2005:16, 192-193). The main emphasis, however, lies on distinction. Faith and science focus on different types of realities (2005:180). They 'make different types of knowledge claims' and 'seldom talk about the same type of reality' (2005:190). Faith is about certainty whilst science is about criticism (2005:185-187). Science is objective whilst faith is subjective (2005:188-189). The most important issue seems to be the ability to distinguish between them: When the church preaches the Ptolemaic system or when Dawkins campaigns against Christianity, they are both guilty of confusing the two (2005:190-192). Admittedly, Van Niekerk (2005:16) does not promote living in 'different compartments' with 'totally incompatible rules' (isolation does not mean opposition). Nowadays it is, however, difficult to link the two compartments as faith 'clashes directly with the insight of our common sense and with the almost undisputable evidence of science' (2005:16). Yet the hope for concordance is not totally given up.

\section{Concordance}

The practical effect of concordance is to accommodate Christianity to science and scholarship. In its search for 'respectability', it will forever try to show that Christianity has nothing to complain about modern science, and it can live quite comfortably 'alongside' it. More positively, this approach tries to link faith and science in an attitude of respect and confidence. Was not science itself born in a Christian environment? Is concordance not better than the dis-cordance experienced by so many between the church and the faculty?

The harmonising attitude emerges, for example, when it comes to the age-old issue of the creation-evolution debate. If I am allowed to leave apart specific authors for a moment and to focus on ideas, consider for example how in some circles the 'days' of Genesis 1 became the long eras accredited by modern science, whilst God's creational fiat could be imagined as a 'big bang'.

This approach is not without its problems. The Bible should be understood for what is says and not constantly adapted to our latest theories. True, in our exegesis, we are influenced by our culture, and science is part of culture. Yet, Blocher (1984:25) is right when saying that, in biblical exegesis, science and scholarship should have a ministerial role, not a magisterial one. Secondly, science is not a monolithic block, and one can only please a few scientists at a time (whilst displeasing others who support rival theories). Finally, scientists are not easily 'pleased' by what they sometimes perceive as a chameleon-strategy (i.e. changing when the theories change).

Concordance is not too far from Liberal identification (which is often more palatable to secular scientists). On the one hand, concordance does not identify its position with a secular one, but on the other hand, it often opens the door, in practice, for the domination of secular science on Christian theorising.

Generally speaking, concordance will never oppose secular positions with determination (e.g. in ethical matters) on the basis of a Christian standpoint. Whenever a secular position is widely accepted, the 'harmonisers' are likely to plead for its acceptance within the Christian community. ${ }^{10}$ One must admit that the Catholic approach is much more 'resistant'. The same can be said about the Anabaptist approach, to which we may now turn.

\section{The Anabaptist approach An oppositional stance}

Instead of parallelism, the Anabaptist tradition ${ }^{11}$ posits a basic conflict between nature and grace. Why should one try to reconcile Christian doctrine with secular science? Christianity may have something to do with a 'natural' revelation, but it has much more to do with the written revelation, regarded as supra-natural. Is not secular science heavily influenced by the secular spirit which shapes and determines its problems, its questions and its solutions?

The moment of truth in this approach (cf. Blocher 1984:21-22) is the intuition that rationality is not neutral and that secular science can be evaluated in its fundamental assumptions and crypto-religious commitments. This is a very valuable insight, which is shared by the reformational approach but is completely absent in all the others. The absence of such insight is due to the very structure of these worldviews, ${ }^{12}$ and it curtails one's understanding of secular scholarship quite severely.

Even in the Anabaptist approach, two alternative versions of the basic paradigm can be distinguished. Given the conflict, grace can protect itself from nature or can try to overcome nature.

The first option is a strategy of separation: Create your own community and cultivate your alternative culture within it, without much contact with the 'world'. (This is the route followed e.g. by many Amish and Mennonite communities in America). In this case, the worldview is not too far from the isolation version of the Lutheran approach and from the

10.For example, some experience it as intolerable that there may be hesitations to elect women as elders and preachers, and they react with deep emotional distress. Without siding with any position, I wonder whether, in some cases, such established (secular) trends of thought which are enjoying large consensus.

11. Which groups adopt an 'Anabaptist' worldview today? I would say, for example, many Pentecostal, Charismatic and Evangelical circles. Veenhof (1994:12) includes the Methodist movement and Olthuis (1970:121) includes Barth in this group.

12.See footnote 4 above. 
mystical or monastic version of the Catholic model mentioned above, ${ }^{13}$ but it constitutes a more radical version of the two.

There is also a second strategy available to the Anabaptists: They may decide to try and overpower the secular Leviathan. The basic idea of the substitution strategy is that 'nature' can be uprooted and replaced by 'grace'. This is, for example, what happened during the revolts of Münster (1534) or in other revolutionary attempts at establishing some or another 'republic of the saints'.

From this particular point of view, one may consider the Anabaptist approach as the opposite of the Lutheran approach: Instead of positing harmony between nature and grace, a basic conflict is assumed. And yet, we can observe that the two approaches present some convergent traits, especially between Lutheran isolation and Anabaptist separation. Let us present some concrete examples of Anabaptist approaches.

\section{Examples of separation and substitution}

In the separation-group, we do not have many examples simply because its members avoid the problem of relating Christianity to scholarship and science. In this perspective, Christianity is not about rationality but about faith, and there is little sympathy even for a science of faith (theology). Perhaps the political proposals of Yoder (1994) may be regarded as examples of separatist scholarship.

Do examples of the second approach (i.e. substitution) exist? Some will be surprised at my hypothesis that this version of the Anabaptist worldview may be shaping the Theonomic or Reconstructionist movements. The latter is not easily or intuitively associated with Anabaptism because of its adoption of reformed 'vocabulary' and doctrine, its origins in the Presbyterian circles of North America and its association with Kuyper and Van Til. And yet, I find in this group exactly an attempt at 'overpowering' nature with grace. This is attempted, for example, in the project of replacing the American legislation with laws obtained directly from the Bible. The Anabaptists did the same in Münster, with some uncertainties concerning whether only the New Testaments or the whole Bible should constitute their legislation. Theonomists are not the only movement supporting a Christian influence in legislation, of course, but their 'replacement' strategy is quite unique.

A similar attitude is sometimes adopted in the creationevolution debate. For most Christians, the first chapters of Genesis provide general guidelines to understand several facets of our universe (in this, they rightly oppose isolationist parallelism). For the Creationist, however, such information is to be taken literally, it is scientific in character, and it constitutes a sort of historical record. It is then used to undertake (replace) whatever information is provided by secular natural-scientific circles.

13.In support of this thesis, one may notice that similar 'withdrawal' movements appeared in all these confessional circles: monasticism in Roman Catholicism, pietism in Lutheranism and spiritualism in Anabaptist circles.
The 'moment of truth' in this attitude is the realisation that science is never neutral, and often, what is smuggled as factual discovery is just appealing theory. Nevertheless, replacing whatever theory with data obtained from a literalist understanding of Scripture is only possible within an Anabaptist 'paradigm'.

Klapwijk $(2008: 10,22)$ regards this branch of creationism as performing a biblicist adaptation or 'intertwinement', but in my opinion, Blocher (1984:19) better understands this approach when he defines it as 'anti-intellectual'. He recalls that the prefix anti originally means both 'against' and 'in the place of'. In some instances, creationism betrays precisely the desire to abolish secular science and to substitute it with the Bible, in a strategy in which grace overwhelms nature.

It is interesting to note that many in the Theonomic movement (including a major figure like Rushdoony) are in fact creationists. In terms of our worldview-analysis, this is hardly surprising. It may also be interesting to know that the creationist movement in the USA received strong impulse from Adventist circles (Numbers 1992), in which the Anabaptist worldview was dominant. ${ }^{14}$

\section{The Liberal approach Basic characteristics}

Even this group is not identifiable with a specific Christian church or confession. Theologically speaking, it affects most denominations. The Liberal worldview approaches the relationship between nature and grace by identifying some parts or dimensions of 'nature' as belonging to or constituting the sphere of grace. Two versions are available: adoption and elaboration. One may find in this approach an inclination to simply adopt certain trends in philosophy (biology, politics, etc.) as representing the Christian position. In some cases, however, the adopted theory (or point of view, position and so on) becomes a starting point to elaborate the Christian position in further areas of reflection.

Basically, whilst in the Catholic tradition there is an attempt at influencing secular scholarship through theology, in the Liberal tradition secular scholarship is invited to influence and even shape Christian theology. In this sense, perhaps the Liberal worldview could be described by the formula 'nature above grace' (see fn. 8), which is the opposite of the Catholic approach. Or should rather the Anabaptist worldview be regarded as the opposite of the Liberal approach (see Olthuis 1970)? After all, in the Anabaptist model, we find opposition to (instead of identification with) a 'natural' trend. Whatever the answer, let us move to some concrete examples.

14. Numbers reports strong opposition to belief in evolution amongst Adventists, during the lifetime (1827-1915) of Ellen White, founder of the movement. Soon after, during the 1920s and 1930s, the Adventist George McCready Price revived after, during the 1920 s and 1930 s, the Adventist George McCready Price revived
the 18th century flood-geology theory. Current acceptance of this theory amongst the 18 th century flood-geology theory. Current acceptance of this theory amongst
creationists can be traced to Price's efforts. In fact, before 1960, the idea that creationists can be traced to Price's efforts. In fact, before 1960, the idea that
earth's rock, layers and sediments could be explained by the flood was mostly confined to Seventh Day Adventist circles. 


\section{Examples of adoption and elaboration}

One particular method, often revealing adoption-inclinations, consists of identifying two or more trends within secular philosophy (or politics, or any other discipline), evaluating them and finally choosing the most 'appropriate' one. That option, trend or theory is then 'baptised' as the Christian position.

Whether this attitude is perhaps partially present in Klapwijk's (1986) proposal of selecting ideas from secular philosophy and integrating them into a reformational worldview (discussed below), is something which might be worth debating. It should be noticed, however, that in addition to such 'appropriations', Klapwijk prescribes a previous transformation (sometimes called alteration) of the ideas to be introduced in a Christian (in his case reformational) worldview.

By contrast, this transformation or alteration phase is rather absent in the more recent writings of a well-known reformed scholar, Nicholas Wolterstorff. Since the middle 1980s, he has gradually abandoned the idea of elaborating new theories on the basis of an original Christian standpoint ${ }^{15}$ and rather supports the adoption of already existing theories mostly supplied by secular circles. In this sense, he recommends the 'weighing' (Wolterstorff 1989:56-80) of secular or humanist theories in order to appropriate the more suitable or tolerable ones to the Christian scholar. Along the same lines, he (1989:70ff.) argues that Christian scholarship is not always or necessarily 'different' from sound secular scholarship.

In a review of Until justice and peace embrace (Wolterstorff 1983), Marshall (1985) lucidly comments:

The first four chapters of the book, which comprise its systematic core, each lay out two options, insist that we must choose between the two options, and argue for the choice of a particular one. (...) Chapter 2 [calls for] a choice between 'modernization' theory and 'world system' theory; (...) Chapter 4 between the rich and the poor. (...) Christian understanding of the modern world is posed as a type of choice between pre-existing theories. (p. 91)

Coming to the second version of the Liberal paradigm, examples of elaboration-approaches are provided by Barbour, Van Huyssteen and Peacocke. Here, secular trends are not only adopted but also used to elaborate and shape Christian scholarship (in many cases restricted to theology).

Concerning Barbour, his work is shaped by a modern-science ideology. Another book review, in this case by Goheen (1992), criticises the starting point from which Barbour's Religion in an age of science (1990) was written:

The first problem surfaces in the opening questions that set the agenda for this book: 'What is the place of religion in an age of science? What view of God is consistent with the scientific understanding of the world?' (...) The modern scientific worldview

15.In the second half of Wolterstorff's Reason within the bounds of religion (1976:59103), there are at least 32 instances in which the term 'weighing' is constantly coupled with the term 'devising' (of new theories) or its synonyms. None of the two terms appears without the other. However, 13 years later in the essay On two terms appears without the other. However, 13 years later in the essay On
Christian learning (1989), only the term weighing is maintained whilst the term Christian learning (1989), only the
devising is no longer to be found. is taken as the plausibility structure for the entire discussion. One's task is then to find a place for faith and theology within the reigning scientific worldview. (...) But it seems to me that this is backwards. The responsibility of the Christian is to attempt the much more difficult enterprise of trying to understand the place of modern science in the light of the Scriptures. (p. 25)

Coming to a second example, Van Huyssteen's theology is deliberately based on evolutionary theory. The title of his 1998 book, Duel or duet?, gives the impression that he wants to create a sort of harmonious relationship between theology and science, pointing towards a Lutheran worldview. In fact, the 'duel' option (i.e. opposition) is out of question. Yet, what he proposes is a model in which evolutionary science completely shapes and determines his theorising.

Peacocke's theology, by contrast, is sshaped by philosophy especially, more precisely by a panentheist ontology (Peacocke 2001:xvii; 57-58). Panentheism (meaning: everything is in God) is similar to pantheism (everything is God). Whilst the latter holds that nature is divine [Deus sive natura], Panentheism teaches that, in ontological terms, creation is in God, or part of God. In this case, God is not identified with creation, but the distinction between creation and creator is definitely compromised. One of the most striking consequences, in my opinion, is that for Peacocke (2001:45), God has only 'probabilistic knowledge' of the future, as he cannot predict events which will take place in this 'open universe'! What can be predicted, I would say, is that when unbiblical ontologies and world-pictures dictate one's doctrine of God, the results can only be perplexing.

These are a few examples of Liberal theorising controlled by secular starting points, and with this, we have also reached the end of our examination of the nature-grace worldviews. Let us now move to the reformational approach.

\section{The reformational approach A transformational approach}

The reformational approach aims at inner reformation. Its three central 'moments' are creation, fall and redemption, corresponding to the central religious motive of the biblical revelation. Instead of dividing the world into a natural and a spiritual sphere, it regards everything in the world as equally created, fallen, but also open to redemption. According to Dooyeweerd, it was the model adopted by Augustine, Calvin and Kuyper. We can understand it better by contrasting it with the nature-grace worldviews.

This approach does not regard some sciences as especially related to the sphere of grace and the others as related to 'nature'. In addition, it does not relate theology to faith especially and the rest of scholarship to reason. It rather relates all the sciences to both faith and reason, and both faith and reason are rooted in a religious motif. This is true of all schools and traditions, Christian or non-Christian.

In fact, theology is as related to scientific reason as science or philosophy are, and both are also connected to a religious 
ground motive which 'directs' reason in a particular direction (towards or away from God's revelation). Theology is a science, not because Lakatos says so but because its point of entry to the study of reality is a modal aspect of created reality (Coletto 2011a:73; 76-77). Secular science is not without its own religious foundation, and Christian spirituality is not without its own scholarly expressions.

The pretension that secular science is somehow 'neutral' and the Christian 'faith' is detached from scholarship should therefore be un-masked. One of the premises often adopted by authors in the 'integration movement' (Van der Walt 2005) is that theology is inherently Christian whilst the other sciences are inherently neutral or secular. Along this line of discourse, the dialogue between Christian and non-Christian scholars is supposed to be mainly a dialogue between Christian theologians and non-Christian scientists or scholars. From a reformational perspective, in contrast, such dialogue should take place between Christian and nonChristian scholarship. In fact, philosophy, biology, history, law and all other disciplines can be Christian or non-Christian in their orientation.

The impression that modern science enjoys unlimited credibility should be radically revised and adjusted, at least to the developments of contemporary philosophy of science since Kuhn, Toulmin and others. We are not living in a 'scientific age' anymore (a phrase appearing often in integration-literature). We live in a postmodern culture in which rationality has been drastically resized, and other agencies lead the dances.

The reason why sound Christian theology does not earn the respect of all does not lie mainly in its lack of 'scientific status'. Here a gross under-estimation of the religious antithesis is at work, together with an illusion created by the absolute lack of transcendental critique, namely that integrating Christian theology with 'neutral' (in fact: secular) science will restore the credibility of theology.

\section{Examples of inner reformation}

Apart from its contributions in the special disciplines, the reformational movement has shaped a whole Christian philosophy in the reformed tradition, and I think this is sufficient proof of its transformational attitude. In comparison with other traditions, a Catholic philosophy exists but is to a large extent the result of a synthesis. Liberal philosophy is secular philosophy produced by Christians. For the rest, there is no Pentecostal, Lutheran, Methodist or Anglican philosophy. Of course, there are philosophers who are members of Lutheran or Anglican communities, but no truly Christian philosophy has been erected on the basis of those worldviews. ${ }^{16}$

When confronted with the multi-vocal trends of the humanist culture, the reformational position tends to appreciate the moments of truth in the different trends but is not inclined to identify with one of them. It also avoids the simple adoption of a via media, which is in many cases a mere compromise between two humanist extremities. It rather tends to create a 'third way' which is often a way out of humanist (or scholastic) dilemmas.

My main example in this context is the reflection on the ageold problem of the universals, originating the conflict between realism and nominalism. Whilst for example Wolterstorff (1970) has simply adopted realism, Hart (1984) has followed a reformational attitude. Alhough appreciating the moments of truth in both realism and nominalism, he elaborated a 'third way' in which the universals are regarded as 'nomic conditions' (i.e. God's structural order for creation).

As I have often mentioned the creation-evolution debate in the previous pages, in this context, one major characteristic of the reformational approach has been a Christian critique of the basic assumptions of evolutionism (cf. Hart 1984:135-144; Strauss 2009:105-118). Such critique then moved towards the identification of several flaws (e.g. concerning change and constancy, the confusion between the biotic and physical modalities and so on). The creationist position, however, has been criticised as well (e.g. Clouser 2006:49-54). Furthermore, in view of a more positive contribution, Klapwijk (2008) has, for example, revisited the idea of 'emergence' in an original way, and Strauss has linked the discussion to the role of distinct type laws. He notices that scientific evidence still points towards discontinuous diversity, rather reflecting the ordering of such laws.

\section{Recommended}

When considering the above, it can be concluded that the reformational worldview is preferable and should be adopted by committed Christian scholars in all fields. The central 'moments' of the reformational worldview (creation, fall and redemption) correspond to the central religious motive of the biblical revelation. This is not the case with the nature-grace approaches: They may be called 'Christian' because they are popular in Christian circles but not because they are biblical in any integral sense. In fact, they correspond to a religious ground motive implying a synthesis between the Christian religion and a secular heritage. The nature-grace motive has challenged the biblical ground motive since the patristic era but managed to 'overtake' it especially during the 13th century, with the advent of the Aristotelian 'renaissance'.

Once the scholastic motive prevailed, the possibility of a truly biblical standpoint in Christian scholarship was compromised, and an attitude of synthesis and accommodation prevailed. In the Catholic approach, Greek ontology was accommodated to the ecclesiastical doctrine without realising that it is basically incompatible with the biblical idea of creation, with the unity of the human being and with other fundamental biblical themes (cf. Strauss \& Bos 1999).

Even in our times, the nature-grace 'paradigm' is responsible for drawing many Christian circles into pseudo-problems, often accompanied by pseudo-solutions. The problem of 
the integration of Christian theology and secular science is to a large extent one of these problems. I realise that the integration-movement (cf. Sinnema 2001; Van der Walt 2005) is popular, powerful and even wealthy, as it is supported by a large 'federation' of nature-grace approaches. Yet a solid biblical approach is to be preferred.

This article could be concluded here, but I suspect that some of the readers might ask themselves at this point whether it would not be better to endorse a combination of approaches, perhaps even adopting all the Christian worldviews together. Is it not better to be inclusive rather than exclusive? The possibility of an eclectic approach will therefore be explored in the following sections.

\section{Mixing the worldviews Is it possible?}

We should start from the question: Is it possible to 'mix' the worldviews and the approaches? I think it is. A person can only hold one worldview at a time, but in some cases, a secular standpoint is directly incorporated in the nature-pole of a nature-grace approach, thus achieving a kind of fusion. Thomas Aquinas, for example, incorporated the Aristotelian form-matter approach within the nature-pole of his own (nature-grace) approach (Dooyeweerd 1959:41ff.). Although Strauss and Bos (1999) have convincingly shown that biblical doctrine and classical Greek cosmology are incompatible, the two can become partners de facto.

Mixing some of the nature-grace types of worldviews is also possible de facto because they share the common denominator of the nature-grace distinction. Even in this case, however, it should be observed that not all the combinations are equally plausible, and some nature-grace worldviews are fairly incompatible with others. For example, trying to combine together Anabaptism and Liberalism or adopting them in different areas of reflection can easily result in all sorts of tensions.

\section{Example of a 'mixed' approach}

My main example of a mixed approach is the work of Polanyi, considered by some the Christian philosopher of science. Polanyi's personal religious journey was an intense one. Born in a Jewish family, he was baptised in the Catholic Church as he approached his thirties. He became also wellacquainted with Protestantism (perhaps in Hungary or during the periods he lived in Germany and England). One can indeed detect many hints of a Catholic position in his Science, faith and society (Polanyi 1946). ${ }^{17}$ In the same work, one can also find clues of his admiration for the Protestant faith. ${ }^{18}$ It is difficult to say whether he adopted a fusion of Christian worldviews.

17.See for example his emphasis on themes like tradition, authority (Polanyi 1946:15) and hierarchy (p. 48). The transmission of scientific expertise is portrayed as a kind
of 'apostolic succession' (p. 44). Knowledge is related to faith according to the of 'apostolic succession' (p. 44). Knowledge is related to
Church Fathers' formula: fides quaerens intellectum (p. 45).

18.For example, Polanyi (1946:56ff.) notices that science has no pope, that is its authority is not centralised but distributed. For Polanyi, this is necessary to preserve the scientific enterprise.
However, one can also detect a more secular (humanist) worldview informing some areas of Polanyi's philosophical reflection. Anastasiou (1979:104-105) shows that the philosophy of the Hungarian thinker is characterised by a Christian approach to epistemology and a humanist (i.e. vitalist-like) approach to ontology. Indeed, in his later works, Polanyi developed what I have called (Coletto 2007:115) a 'late-modern line', which is not much dissimilar from Kuhn's partially relativist approach.

Polanyi might therefore have 'mixed' not only Christian worldviews but also Christian and humanist worldviews. It should be noticed, however, that the price he had to pay for it was a gradual drift into partially-subjectivist positions (Coletto 2007:121-123). The synthesis between Christian and secular ideas and views is an attempt at uniting iron and clay (Vollenhoven 1933:16, 306) or at building on the sand: It may work for a while, but it is never advisable. One may still be a great scholar, but not a great Christian scholar.

Even though some of the worldviews characterised by the nature-grace denominator may be partially compatible, adopting uneven approaches in scholarship will easily result in tensions. Finally, those who adopt the reformational approach should be aware that they choose a worldview which is largely incompatible with the nature-grace patterns. This does of course not mean that there cannot be communication, appreciation, cooperation or whatever other form of interaction. It simply means that interaction is different from confusion.

\section{Final remarks}

Van der Walt (1994:108) warns us that, when it comes to worldviews, it is possible and even easy to be unfair towards other positions. It is also easy to be flattering and idealistic towards one's own position. I have therefore tried to be fair in presenting the major Christian worldviews and their implications for science and scholarship. By exploring a range of examples, I trust that I have argued that different attitudes towards scholarship are informed by the basic 'prescriptions' provided by worldviews.

I trust that I have also shown that the Christian approaches are not 'just the same'. I have also indicated which worldview should be preferred by the Christian scholar (i.e. the reformational worldview), due to the fact that it reflects the central biblical motive in a fuller and more integral way. Without downplaying other approaches completely, and without disregarding dialogue and interaction, I have argued that the reformational worldview provides the most consistent biblical approach.

I would like to conclude this article with a call to consistency. On the one hand, it is directed to all Christian academics, urging the adoption of a reformational worldview, for the reasons discussed above.

On the other hand, this call is particularly directed to Christians from reformed circles. Too often Christian academics who regard themselves as belonging to this 
confessional tradition adopt in fact positions and strategies which have little to do with it. We have theologians and pastors who plan to work within a reformed community on the basis of some neo-Thomistic or quasi-Pentecostal worldview. We have academics attending a reformed church, voting for a liberal party and promoting postmodernist scholarship. Some are positivists in philosophy, pragmatists in their career, conservative in their ethics and so on and on. Whilst psychological assistance may in some cases help to a certain extent, a better understanding of the differences amongst worldviews might help improving one's consistency even more.

\section{Acknowledgements Competing interests}

I declare that I have no significant competing financial, professional or personal interest that might have influenced the performance of the work described in this manuscript.

\section{References}

Anastasiou, H., 1979, 'Faith knowledge and science: A systematic exposition of the thought of Michael Polanyi', Master's Thesis, Department of Philosophy, Institute for Christian Studies, Toronto.

Barbour, I., 1990, Religion in an age of science, Harper \& Row, New York, NY

Bavinck, H., 1888, De katholiciteit van christendom en kerk, Kampen Teologische Universiteit, Kampen.

Blocher, H., 1984, La creazione, l'inizio della Genesi, G.B.U., Roma.

Clouser, R.A., 2006, 'Genesis re-gained: Creation, not creationism', Tydskrif vir Christelike Wetenskap/ Journal of Christian Scholarship 42(Spesiale Uitgawe 1), 49-64.

Coletto, R., 2007, 'The legitimacy crisis of science in late-modern philosophy: Towards a reformational response', Doctoral thesis, Department of Philosophy, NorthWest University, Potchefstroom.

Coletto, R., 2009, 'Christian scholarship within reformed circles', Acta Academica 41(3), 16-41.

Coletto, R., 2011a, 'Science and non-science: The search for a demarcation criterion in the 20th century', Journal for Christian Scholarship 47(1), 63-79.

Coletto, R., 2011b, 'The elaboration of a demarcation criterion in reformational philosophy', Acta Academica 43(2), 41-65.

Dooyeweerd, H., 1959, 'Cinq conferences', La revue réformée 10(3), 3-76.

Dooyeweerd, H., 1984, A new critique of theoretical thought, Paideia Press, Jordan Station.

Frame, J.M., 1987, The doctrine of the knowledge of God, Presbyterian and Reformed Publishing Company, Phillipsburg, NJ.

Goheen, M., 1992, 'Book review', Pro rege 20(4), 25-26.

Hart, H., 1984, Understanding our world: An integral ontology, University Press of America, Lanham, MD.
Klapwijk, J., 1986, 'Antithesis, synthesis and the idea of transformational philosophy', Philosophia Reformata 51(1/2), 138-152.

Klapwijk, J., 2008, Purpose in the living world? Creation and emergent evolution, Cambridge University Press, Cambridge. http://dx.doi.org/10.1017/CBO9780511813818

Marshall, P., 1985, 'Book review', Philosophia reformata 50(1), 89-93.

Murphy, N., 1985, 'Theology: The transformer of science: A Neibuhrian typology for the relation of theology to science', Pacific theological review 18(1), 16-23.

Murphy, N., 1990, Theology in the age of scientific reasoning, Cornell University Press, Ithaca and London.

Niebuhr, H.R., 1956, Christ and culture, Harper \& Row, New York, NY.

Numbers, R.L., 1992, The evolution of scientific creationism, A.A. Knopf, New York, NY. Olthuis, J.H., 1970, 'Must the church become secular?', in J. Olthuis, H. Hart \& C. Seerveld (eds.), Out of concern for the church, pp. 105-125, Wedge, Toronto.

Peacocke, A., 2001, Paths from science towards God: The end of all our exploring, Oneworld Publications, Oxford.

Pierson, G.N., 2009, 'Evangelicals and worldview confusion', in J.M. Bonzo \& M. Stevens (eds.), After worldview: Christian higher education in postmodern worlds, pp. 29-42, Dordt College Press, Sioux Centre.

Polanyi, M., 1946, Science, faith and society, University of Chicago Press, Chicago, IL.

Sinnema, D., 2001, 'Beyond integration to holistic Christian scholarship', in J.H. Kok (ed.), Marginal resistance: Essays dedicated to J.C. Vander Stelt, pp. 187-208, Dordt College Press, Sioux Center.

Strauss, D.F.M., 2009, Philosophy: The discipline of the disciplines, Paideia Press, Grand Rapids, MI.

Strauss, D.F.M. \& Bos, A.P., 1999, 'Greek ontology and biblical cosmology: An unbridgeable gap', Tydskrif vir Christelike Wetenskap 35(3/4), 137-163.

Van der Walt, B.J., 1994, The liberating message: A Christian worldview for Africa, North-West University (previously Potchefstroom University for C.H.E.) Institute for Reformational Studies, Potchefstroom.

Van der Walt, B.J., 2001, 'The shape of an integral cosmoscope', in J.H. Kok, (ed.), Marginal resistance: essays dedicated to J.C. Vander Stelt, pp. 71-88, Dordt College Press, Sioux Center.

Van der Walt, B.J., 2005, "Integration or transformation? "Faith and scholarship" or "faith directed scholarship" as a starting point for Christian scientific endeavour', in B.J. van der Walt (ed.), Transforming power: Challenging the contemporary secular society, pp. 319-346, Institute for Contemporary Christianity in Africa, Potchefstroom.

Van Huyssteen, J.W., 1998, Duet or duel?: Theology and science in a postmodern world, Trinity Press International, Harrisburg, PA.

Van Niekerk, A.A., 2005, Geloof sonder sekerhede: Besinning vir eietydse gelowiges, Lux Verbi, Wellington.

Veenhof, J., 1994, The relationship between nature and grace according to H. Bavinck Institute for Reformational Studies, Potchefstroom

Vollenhoven, D.H.Th., 1933, Het calvinisme en de reformatie van de wijsbegeerte, H.J. Paris, Amsterdam.

Wolters, A.M., 1990, 'Christianity and the classics: A typology of attitudes', in W.E. Helleman (ed.), Christianity and the classics, pp. 189-203, University Press of America, Lanham, MD.

Wolterstorff, N.P., 1970, On universals: An essay in ontology, University of Chicago Press, Chicago, IL.

Wolterstorff, N.P., 1976, Reason within the bounds of religion, Eerdmans, Grand Rapids, MI.

Wolterstorff, N.P., 1983, Until justice and peace embrace, Eerdmans, Grand Rapids, MI.

Wolterstorff, N.P., 1989, 'On Christian learning', in P.A. Marshall, S. Griffioen \& R.J. Mouw (eds.), Stained glass: Worldviews and social science, pp. 56-80, University Press of America, Lanham, MD.

Yoder, J.H., 1994, The politics of Jesus, Eerdmans, Grand Rapids, MI. 